$\mathbb{T}$ periodica polytechnica

Social and Management Sciences

$15 / 1$ (2007) 11-22

doi: 10.3311/pp.so.2007-1.02

web: http://www.pp.bme.hu/so

(c) Periodica Polytechnica 2007

RESEARCH ARTICLE

\section{The socioeconomic background of the divergence of Belarusian and Ukrainian Political Systems}

\author{
Ádám Mészáros / Zsolt Szabó
}

Received 2008-09-14

\begin{abstract}
The aim of this paper is to analyse the political, social and economic background of the divergence of Belarusian and Ukrainian transitions. We focus on Belarus in order to find explanation for questions such as why could Lukashenko remain the authoritarian leader of Belarus, while in Ukraine the position of the political elite had proved less stable and collapsed in 2004. On the theoretical framework of elite-sociology, we seek to determine whether the internal factors (as macroeconomic conditions, standard of living, the oppressive nature of the political system and the structure of the political elite) play a significant role in the operation of the domino effect. This article emphasises the determining role of immanent internal factors, thus the political stability in Belarus can be explained by the role of the suppressing political regime, the hindrance of democratic rights and the relatively good living conditions that followed the transformational recession. Whilst in Ukraine, the markedly different circumstances brought forth the success of the Orange Revolution.
\end{abstract}

\section{Keywords}

social institutions - legal institutions · voting behaviour . elites $\cdot$ economic transition

\section{Acknowledgement}

We thank András Blahó, Júlia Palotás, Barbara Lovas, Steven Richardson, and László Vigh for their very helpful comments and suggestions. The usual disclaimers apply.

\section{Ádám Mészáros}

International Business Research Centre, Corvinus University of Budapest, H1093 Budapest, Fővám tér 8., Hungary

e-mail: adam.meszaros@uni-corvinus.hu

\section{Zsolt Szabó}

Department of World Economy, Corvinus University of Budapest, H-1093 Budapest, Fővám tér 8., Hungary

e-mail: zsolt.szabo@uni-corvinus.hu

\section{Introduction}

The political and economical transition of the Post-Soviet states has been far from a straightforward change into democracy and market economy. As Merkel remarked, in 1994 [32] even at the beginning of the transition period, it is impossible to create a general theory of transition. This process is analysed in detail from several perspectives, however, most of them deal with elite strategies and do not focus on social processes and social pressure on elite decisions (Whitehead, 2001 [59]).The aspect of this paper is unique because we try to synthetize the political, social and economic aspect of transition. Our aim is to analyse the socioeconomic background of the divergence of Belarussian and Ukrainian transitions. The differences in the methods of designing the transformation were recognizable by the mid 1990's (Portes, 1994 [42]). The "traps" and difficulties of the transformation have been evident since then. The authoritarian regimes concerning the number of the region's countries have recently collapsed, like in Georgia, Ukraine or Kyrgyzstan. Social discontent, which proved to be one of the major catalysts of the changes in these countries, has not gone large-scale in Belarus yet. Why is the power of the Belarus elite stronger than that of other elites in the process of democratization? If the transition is regarded as an elite-driven process, the question arises: in what degree is it due to the oppressing nature of the regime, and to what extent can it be explained by economic recession, or its effects on society.

In this essay we focus on Ukraine and Belarus, the two largest Western neighbours of Russia, in order to find an explanation as to why Alexander Lukashenko was able to remain in power while in Ukraine the power of the elite had proven to be weaker and collapsed at the end of 2004. According to this study, the accumulation of political and societal discontent and the existence of the forums and institutions articulating these views have made together the political changes possible by the end of 2004 . In Belarus, due to the restricted access to the democratic forums and the internal support of the political elite, which stems from the relatively good economic results of the country, it meant that the force of the social movements has been relatively weak. In other words, using Polanyi's methodology, we can say that the 
Belarusian society is in contrast with the Ukrainian that has not had to respond in any way to the market impulses to protect itself (Polanyi, 1942 [40]). In Belarus there has neither been any strong pressure on the society to react against capitalism and transformation, nor any effective channels to influence the first period of transition.

Transformation is a process that depends on three main groups of factors: the initial conditions, the policies pursued, and the external environment (Ellman, 1994 [8]). Some theorists (see the classic work of. Lipset, 1959 [30]) analysed the socioeconomic requisites of democratic regimes. Certain researchers point to external forces (see e.g. Vachudova, 2006 [55]). Geopolitics and the political and economic support of Russia, the EU and the US are two great powers that play an important role in the maintenance of the elite's power or in the possible rise of power of the opposition. The domino effect theory, which has often been used for the analysis of the Cold War, can also be adopted for the process of transition; democratization and distancing from the Russian influence (see e.g. Starr, 1991 [48]; Starr - Lindborg, 2003 [49]; Bunce - Wolchnik, 2006 [6]; McFaul, 2005 [31]). We do not deny the statements of pathdependency (Stark, 1992, [46]; Stark, 1995 [47]) and the importance of initial conditions, but we presume that the similar initial conditions in the two countries do not influence the success of the transition processes. Some scholars have asserted that ethnicity has a great impact on the support of democratization and marketization in post-Soviet states (see e.g. Kuzio, 2001 [28]; Eke - Kuzio, 2000 [9]). Their analyses say that ethnic Ukrainians, are more supportive of market economy and democracy than ethnic Russians and Belarussians. Other results focus on both internal and external political effect, but neglect the role of economic situation and social factors (see e.g. Way, 2005 [57], Way, 2006 [58]). Nevertheless, we have to pose the question: under similar geopolitical circumstances, which country is to be considered as a weak domino, and what are the internal factors that play role in answering the question whether discontent can be articulated to and resulted in political changes? This article emphasises the determining role of immanent internal factors, thus the political stability in Belarus can be explained by the role of the suppressing political regime, the hindrance of democratic rights and the relatively good living conditions that followed the transformational collapse, while in Ukraine, the markedly different circumstances brought forth success of the Orange Revolution.

This essay is constituted from the following parts. Firstly, it is argued that the elites play a very prominent role in the transformation of the institutions, especially in the transitional period (see Szalai, 1997 [51]; Szalai, 2001 [52]). Higley and Lengyel 2000 [24] argue that elite configurations influence the operation of institutions in transition. Some scholars suggest that all democratic transitions are the products of elite choices (Higley and Burton, 1989 [22]). By the economic approach presented here, we cast light on the fragility of the elites' position, thus providing an economic explanation for their legitimacy. Secondly, we review the causes of social discontent and their elements of articulation. As follows, we analyse some key indicators of the so called perceived economy and figures of the standard of living, since, according to our hypothesis, the effect of the transition period on the standard of living is a main factor responsible for social discontent. The existence or non-existence of democratic institutions is a key factor of the society's ability to mediate their needs or criticism towards the elite. Finally, we will attempt to summarize the socioeconomic background of the divergence of the two political systems.

\section{Theoretical framework}

\subsection{The elites' institution-forming roles}

Historically, even before the Central-Eastern European transitions, elites and elite settlements have always played a significant role in consolidation of socio-economic systems, as it is empirically verified by Higley and Burton, 1987 [23]. Even the classical elite theories conclude that elite variations have determinate effects on the character of political regimes (Mosca 1939 [34]). The most relevant antecedents of Central-Eastern European transitional and elite theories are the frameworks analyzing the Latin-American and the Southern European transitions. Their consequences are limited: in the bipolar system, under different political and economic circumstances, the role of elites was also different.

Elite-analyses of transforming economies depict the transitions as elite-governed processes (for further explanations, see: Pigenko, Weise and Brown, 2003 [38]). These are in accordance with the observations of neo-institutionalism in those countries or regions where organic, bottom-up and slower-paced institutional development was not possible, the institutions have been installed in a top-to-bottom way (see Szabó, 1994 [50]), to the pattern of foreign examples. Higley and Lengyel, 2000 [24] refine the role of elites because they presume that the relationship between the institutions and the elites is not a one-way road: elites determine institutions and vice versa. They also emphasize the elites' commitment to institutions especially because institutions are in flux and elites have wider latitude of choice and action. The connection between elites and democracy is well disputed in the literature (see Etzioni-Halevy, 1993 [10]).

The intellectual elites of most of the post-socialist countries aimed at the adoption of a democratic and market-economy establishment in order to be able to provide higher standards of living, cultural and political framework for their people. Even in Central Europe, where the democracies developed easier, the elites had a prominent role in the development of the foundations of democracy and the market economy. Theoretically and practically it is necessary to distinguish institutional design and institutional mechanisms. Institutional design (designing the structural elements of the new socio-economic system, for example aiming market economy) is very similar in every country in the region, but the role of elites in institutional mechanisms 
(instruments for implementing design patterns) is highly diverse (Higley and Lengyel, 2000 [24]).

In Eastern Europe, where the process of democratization has some been slower and, may even has stopped altogether in some countries, and where, due to state property or the state's bureaucratic regulatory mechanisms, the political elites have more influence on the economy, it is unquestionable that the transformation is an elite-driven process. We can conclude that the ratio of the elite circulation and the elite reproduction ${ }^{1}$ influences "only" the quality of the resulting system, not the elite-driven nature of the transition (for a more detailed discussion, see Szelényi and Szelényi, 1995 [53]). Furthermore, the absence of any tradition of elite autonomy, and the lack of democratic traditions in the Post-Soviet states make democracy not a likely outcome (Etzioni-Halevy, 1993 [10]).

Depending on the configuration of national elites several regime types can come into existence. Elites are wide differentiated when the elite groups are heterogeneous, functionally distinct, autonomous, and organizationally diverse. Conflicts, deep hostilities are common. Elite unity means that the different groups of elite share common values; there are norms which are accepted by them, they share their political understanding about the proprieties of political conduct. Higley and Burton 1989 [22] remark that the unity of national elites is one of the most important determinants of regime forms. Table 1 shows the possible outcomes.

The main consequence of elite disunity is regime instability. The elite circulation patterns depend on the mode and scope of changing in the structure of the elite according to Table 2.

Lengyel and Higley draw the conclusion that these patterns can be paired according to Table 3 .

The later chapters explain that the Belarussian system without relevant opposition, with narrow elite differentiation and with strong elite unity is a typical totalitarian regime. According to this theoretical framework the elite circulation could be deep, wide and sudden there. In today's Ukraine, where the different groups of elite seem to be highly differentiated and the unity of elites is weak, there is a typically unconsolidated democracy, where theoretically the reproduction circulation is the typical pattern. As Higley and Burton 1989 [22] remark, a disunified national elite produces a series of unstable regimes.

In Belarus, the elite reproduction, moreover the elite continuity has not resulted in a markedly different political establishment, and the economic transition is in a strange borderline on the market economies typical of our region and that of statedominated economy. It was not in the interests of the political elite to convert some of their political capital into economic capital, since they were able to retain their power even after the 1990 's and they could postpone the forming of the new estab-

\footnotetext{
${ }^{1}$ Based on their article, we consider the circulation of elites as the emergence of new people of different social classes. The elite reproduction is a process which does not change the social composition of the elite.
}

lishment and the defining of the conversion ratios.

The key players of the present Ukrainian political elite: Yulia Timoshenko, Viktor Yushchenko and Viktor Yanukovich have been in the forefront of Ukrainian politics for years and the Orange Revolution in 2004 merely rearranged the relative positions of the players. Since then we have witnessed the redistribution of power within this elite, but it seems none of the parties are able to expel the other from the political field for a long time. Nevertheless, the different economic lobbies bring a strong pressure on the principal actors of political life.

Due to the interpenetration and traversing between the elite groups we will not discriminate the different groups in this essay. Our approach is positionalist and stratificational, and is based on the role of actors of society. According to the former, we regard the elites as groups of individuals who are in the position of making decisions (Higley and Burton1989 [22]). The stratificational approach assumes that the installation of institutions is a top-down process and it is the elite in position of power who builds and monopolizes the system. Although the relative autonomy of the institutions and their independence from their establishers are subject to professional debate (Greven, 1995 [20]), we assume that the institutions cannot be considered as autonomous agents since it is the individuals (the elite) who determine their character, quality, functions and limits. O'Donell and Schmitter 1986 [37] also emphasize the role of actors and elites, but they promote the democratic changes only if their benefit from transition is higher than their costs of maintaining the authoritarian system.

In spite of these, the economic results and their effects on society are only partly dependent on the system and institutions established and influenced by the elites. Geopolitics, external processes, the collapse of export markets and the transformational recession are all such external circumstances which are beyond the "action radius" of the elites. However, the elites, by their economic policy-making influence on the transition also have an effect on the macroeconomic indicators, just as much as on redistribution or on the ratio of income distribution, etc.

From our point of view, the essence of this approach of examining the transition through economic performance is that economic development and the material prosperity of the society play an important role in the consolidation of the transformed or newly-developed political system (see Plasser-Ulram, 1995 [41]). Their share in shaping the political establishment, extending democratic rights, and creating political institutions is even larger, almost exclusive, especially where traditions of exerting social pressure are weaker, such as in Eastern Europe.

\subsection{The causes of social discontent and their elements of articulation}

We must therefore, investigate the ways the elites influence society, or in other words: what the economic, societal, and institutional factors affecting the social discontent that emerge in the process of economic transition are. Political constraints and 
Tab. 1. Configuration of National Elites and Associated Regime Types

Elite unity

\begin{tabular}{|c|c|c|c|}
\hline \multirow{3}{*}{ Elite differentiation } & & Strong & Weak \\
\hline & Wide & Consensual elite(consolidated democracy) & Fragmented elite(unconsolidated democracy) \\
\hline & Narrow & Ideocratic elite(totalitarian or post-totalitarian regime) & Divided elite(authoritarian or sultanistic) \\
\hline
\end{tabular}

Source: Higley, John - Lengyel, György (eds.): Elites after State Socialism: Theories and Analysis. Lanham, 2000. pp. 3. [24]

Tab. 2. Patterns of Elite Circulation

\begin{tabular}{lccc}
\hline & & \multicolumn{2}{c}{ Scope } \\
\hline & & Wide and deep & Narrow and shallow \\
\cline { 3 - 4 } Mode & Gradual and peaceful & Classic circulation & Reproduction circulation \\
& Sudden and coerced & Replacement circulation & Quasi-replacement circulation \\
\hline Source: Higley, John - Lengyel, György (eds.): Elites after State Socialism: Theories and Analysis. Lanham, 2000. pp. 4. 24]
\end{tabular}

the resistance of society can influence the process of transition for many reasons (Roland, 1994 [43]; Roland, 1997 [44]). Even in the case of Ukraine and Belarus, the autocratic regimes have to respect society: hurting every group and damaging the welfare of society leads to social discontent. Sanders (1995) [45] argued that politicians have to distinguish real economy and perceived economy and other empirical studies (for example Niemi, Bremer and Heel, 1999 [36]) have shown the importance of perceived economy in elections. Society only perceives a fraction of the macroeconomic indicators of the transformational recession, for example the changes in real wages, inflation, economic growth, unemployment rate, the amount of GDP per capita and its growth rate. For the society, these factors are the indicators of perceived economy.

The external or internal imbalances or structural problems, even if they are unsustainable in the long run, do not lead to social discontent until they have an effect (by a minor adjustment, economic shock therapy, or large-scale recession) on the perceived economy, that is on the factors mentioned above. ${ }^{2} \mathrm{Nev}$ ertheless, the improvement of the unperceived indicators can actually have a deteriorating effect on the immediately perceivable indicators. Therefore, it seems advisable to focus on those macroeconomic indicators that the society can perceive in the short term, as these have an immediate effect on the social contentment/discontent and its manifestation. Greskovits (1995) [19] argued that the manifestation of social discontent in transitional countries depends greatly on the structure of society, the effects of transition on society, as well as the political system of the country.

The instruments used to express social discontent are funda-

\footnotetext{
${ }^{2}$ With the maintenance and amendment of the perceived economy's indicators, the Hungarian Kádár regime has managed to achieve a certain level of social satisfaction; the structural distortions and imbalances were hidden from the society until the beginning of the transition. Thus, the factors of the percieved economy can differ from the real state of the economy during a considerable period of time. Certainly, this cannot apply automatically for the period of our research: in case of both countries, the collapse in the indicators of the percieved economy was remarkable.
}

mentally different in an established democracy and a dictatorship. In the former, many of the forms of discontent can be handled by the system while it does not touch upon the system's foundations: democtratic systems aid the interests of the majority, which can also mean the replacement of the elite (e.g. with elections). In a dictatorship, the social discontent is directed at the ruling elite and the foundations of the system at the same time. The articulation forms of discontent are systemdependent: civil disobedience can only be efficient in a democracy (see Bence, 1991 [5]) but it is ineffective in a dictatorial state. Revolution is the way to overthrow a dictatorship, and strikes are not an effective measure of social discontent either, if there are no independent unions. Without overgeneralizing in our association of forms of protests and political systems it must be admitted that in an authoritarian state the manifestation of social discontent is more difficult and can even be delayed in manifestation. Measuring it and the reliability of these measurements leave much to be desired. Moreover, the absence of democratic institutions is intended to cover up social discontent. This fact seriously restricts the methodology of the present essay: the traditional forms of protests and the figures representing these can only be used to measure social discontent with limitations.

\section{Transformational recession in Ukraine and Belarus}

All post-Soviet states suffered a major economic recession in the 1990s. The reasons, which were analysed in detail in the literature (see e. g. Williamson, 1993 [60]; Fischer, Sahay, Végh, 1997 [11]), are not important from our point of view. The gravity of the recession is unquestionable, but the question arises whether the Belarussian recession can be regarded as outstanding in the region. Is it possible to explain the measure of social discontent with the gravity of this recession, felt by the whole society? It seems helpful to compare the Belarussian and Ukrainian figures, as the downfall of the Ukrainian regime was largely due to economic reasons, and also because by comparing the two sets of figures we can avoid a possible mistaken conclusion arising from the fact that recession was deeper in Eastern 


\begin{tabular}{|c|c|c|c|}
\hline & \multirow[b]{3}{*}{ Gradual and peaceful } & \multicolumn{2}{|c|}{ Scope } \\
\hline & & Wide and deep & Narrow and shallow \\
\hline & & $\begin{array}{l}\text { Classic circulation: Consensual } \\
\text { elite (consolidated democracy }\end{array}$ & $\begin{array}{l}\text { Reproduction circulation: Frag- } \\
\text { mented elite (unconsolidated } \\
\text { democracy }\end{array}$ \\
\hline & Sudden and coerced & $\begin{array}{l}\text { Replacement circulation: Ideo- } \\
\text { cratic elite (totalitarian or post- } \\
\text { totalitarian regime }\end{array}$ & $\begin{array}{l}\text { Quasi-replacement circulation: Di- } \\
\text { vided elite (authoritarian or sul- } \\
\text { tanistic) }\end{array}$ \\
\hline
\end{tabular}

Source: Higley, John - Lengyel, György (eds.): Elites after State Socialism: Theories and Analysis. Lanham, 2000. pp. 6. [24]

Europe than in the Central European region.

The Belarussian economy did not go through the fundamental structural changes in the last 15 years; the predomination of state property, the sectoral structure inherited from the Soviet system and the bureaucratic governance of the economy are still very typical. The liberalization of prices, started in 1992, as well as the initial impetus of privatization, was stopped by an authoritarian intervention within a couple of years. Table 4 shows those macroeconomic indicators that are perceivable for the society in the short run.

The data above only reveals that the recession was of largescale in both countries. Based on these data it cannot be confirmed that the political changes in Ukraine and Belarus can be linked with the degree of the recession.

However, the reliability of the above data and the drawn conclusions should be approached with due caution. The mere difference between an inflation rate of $891.2 \%$ and another of $2,220.9 \%$ does not necessarily mean a difference in social discontent as well; more important is its effect on the level of real wages. Neither does the official unemployment rate reflect the real activity of the society on the labour market. Nevertheless, it is worth comparing the development of GDP in the two countries.

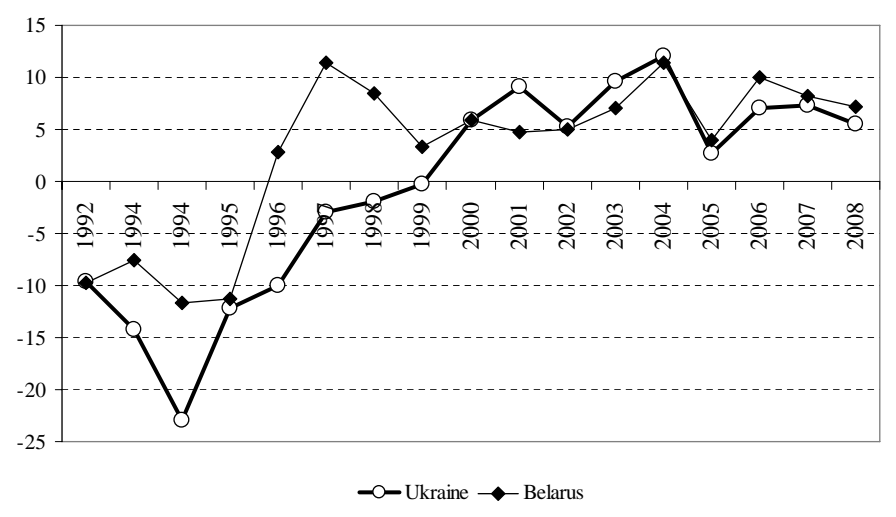

Source: IMF: World Economic Outlook Database, 2008 http://www.imf.org/external/pubs/ft/weo/2008/01/weodata/index.aspx [27]

Fig. 1. Chart 1: GDP Growth in Belarus and Ukraine in Constant Price Level (year-by-year, percentage)

Data show that the Belarussian economy has been on a growth path since 1996, while in Ukraine the economy only started to grow around the turn of the millennium. This suggests that the Ukrainian economy had been slower in getting over a greater transformational shock and thus it had posed a greater burden on the people. The Belarussian economy showed its worst performance in the middle of the 1990's, the annual GDP in 1995 was at 2/3 of that of 1991 (in constant price level). According to the estimates, GDP will be $42 \%$ larger in 2007 than in 1991. In Ukraine, between 1992 and 2000 GDP was less than half of the 1991 level almost every year (IMF, 2008 [27]).

Regarding the GDP per capita in PPP (with 1996 as base year), similar conclusions can be drawn. The Belarussian GDP per capita has doubled between 1995 and 2003, while Ukrainian figures show a different pattern: between 1993 and 2003 the GDP per capita follows a U-shaped pattern, and the level of GDP was only slightly higher at the end of the period than ten years before (IMF, 2008 [27]). There is also a great difference between the two countries in the ratio of consumption to GDP. Since 2001, the value of this indicator has been above $60 \%$ in Belarus, while in Ukraine it was about 55\% during the past ten years. The above indicators suggest that the economic situation perceived by the society has been much more favourable in Belarus.

Altogether, we conclude that the Ukrainian economy has gone through a longer and more serious transitional collapse.

Veress (1999) [56] suggested the calculation of the so-called 'Misery' and 'Unpopularity' indices to examine the relations of economic policy and social contentment/discontent. ${ }^{3}$ The Misery Index and the Unpopularity Index have positive correlation with social discontent, therefore it can be regarded as a rudimentary numerical technique for them.

Contrary to previous data, in the case of these indices one cannot see a considerable dissimilarity between the figures of the two countries. The extremely high values and turbulent behaviour of the indicators are due to the hyperinflation. Using the present weighting scheme, the misery and unpopularity indices tend to disregard the importance of economic growth and

\footnotetext{
${ }^{3}$ Misery index $=$ inflation rate + unemployment rate; unpopularity index = inflation rate $-3 \mathrm{GDP}$ growth
} 
Tab. 4. Inflation, Price Level, Economic Growth and Unemployment in Belarus and Ukraine (1992-2008)

\begin{tabular}{|c|c|c|c|c|c|c|c|c|}
\hline & \multicolumn{2}{|c|}{ Rate of inflation (\%) } & \multicolumn{2}{|c|}{ Price level $(1992=1)$} & \multicolumn{2}{|l|}{$\begin{array}{l}\text { GDP growth, } \\
\text { prices (\%) }\end{array}$} & \multicolumn{2}{|c|}{$\begin{array}{l}\text { Registered unemployment } \\
\text { rate (end of year) }\end{array}$} \\
\hline & Belarus & Ukraine & Belarus & Ukraine & Belarus & Ukraine & Belarus & Ukraine \\
\hline 1992 & 970.3 & $1,210.0$ & 1.0 & 1.0 & -9.6 & -9.7 & 0.5 & $\mathrm{n} / \mathrm{a}$ \\
\hline 1993 & $1,190.2$ & $4,734.9$ & 12.9 & 48.4 & -7.6 & -14.2 & 1.4 & 0.4 \\
\hline 1994 & $2,220.9$ & 891.2 & 299.5 & $479, .2$ & -11.7 & -22.9 & 2.1 & 0.4 \\
\hline 1995 & 709.3 & 376.4 & $2,423.6$ & $2,282.8$ & -11.3 & -12.2 & 2.9 & 0.6 \\
\hline 1996 & 52.7 & 80.2 & $3,700.5$ & $4,114.5$ & 2.8 & -10.0 & 4.0 & 1.5 \\
\hline 1997 & 63.8 & 15.9 & $6,062.2$ & $4,768.0$ & 11.4 & -3.0 & 2.8 & 2.7 \\
\hline 1998 & 73.0 & 10.6 & $10,488.7$ & $5,272.3$ & 8.4 & -1.9 & 2.3 & 4.3 \\
\hline 1999 & 293.7 & 22.7 & $41,297.6$ & $6,468.2$ & 3.4 & -0.2 & 2.1 & 5.5 \\
\hline 2000 & 168.6 & 28.2 & $110,925.8$ & $8,292.5$ & 5.8 & 5.9 & 2.1 & 5.5 \\
\hline 2001 & 61.1 & 12.0 & $178,738.0$ & $9,284.1$ & 4.7 & 9.2 & 2.3 & 4.8 \\
\hline 2002 & 42.6 & 0.8 & $254,823.2$ & $9,354.4$ & 5.0 & 5.2 & 3.0 & 5.0 \\
\hline 2003 & 28.4 & 5.2 & $327,187.9$ & $9,841.8$ & 7.0 & 9.6 & 3.1 & 4.8 \\
\hline 2004 & 18.1 & 9.0 & $386,389.3$ & $10,731.4$ & 11.4 & 12.1 & 1.9 & 4.8 \\
\hline 2005 & 10.3 & 13.4 & $426,326.5$ & $12,171.4$ & 4.0 & 2.7 & 1.5 & 4.3 \\
\hline 2006 & 7.0 & 9.0 & $456,135.2$ & $13,268.0$ & 10.0 & 7.1 & 1.2 & 3.7 \\
\hline 2007 & 8.4 & 12.8 & $494,582.9$ & $14,972.0$ & 8.2 & 7.3 & $\mathrm{n} / \mathrm{a}$ & $n / a$ \\
\hline 2008 & 11.2 & 21.9 & $549,763.5$ & $18,253.8$ & 7.1 & 5.6 & $\mathrm{n} / \mathrm{a}$ & $n / a$ \\
\hline
\end{tabular}

Source: Inflation, economic growth: IMF: World Economic Outlook Database, April 2008,

http://www.imf.org/external/pubs/tt/weo/2008/01/weodata/index.aspx [27]

Price level: IMF: World Economic Outlook Database, April 2008, http://www.imf.org/external/pubs/ft/weo/2008/01/weodata/index.aspx [27], own calculations

Unemployment: ILO: ILO Database' http://laborsta.ilo.org/cgi-bin/brokerv8.exe [25]

Data from 2007 are estimates and from 2008 are forecasts.

Tab. 5. Indices about Social Judgement of Economic Policy in Ukraine and Belarus (1992-2008)

\begin{tabular}{rrrrr}
\hline & Misery index & \multicolumn{3}{c}{ Unpopularity index } \\
\hline & Belarusia & Ukraine & Belarusia & Ukraine \\
\hline 1992 & 970.8 & & 999.1 & $1,239.1$ \\
1993 & $1,191.6$ & $4,735.3$ & 1213 & $4,777.5$ \\
1994 & 2223 & 891.6 & 2256 & 959.9 \\
1995 & 712.2 & 377 & 743.2 & 413 \\
1996 & 56.7 & 81.7 & 44.3 & 110.2 \\
1997 & 66.6 & 18.6 & 29.6 & 24.9 \\
1998 & 75.3 & 14.9 & 47.8 & 16.3 \\
1999 & 295.8 & 28.2 & 283.5 & 23.3 \\
2000 & 170.7 & 33.7 & 151.2 & 10.5 \\
2001 & 63.4 & 16.8 & 47 & -15.6 \\
2002 & 45.6 & 5.8 & 27.6 & -14.8 \\
2003 & 31.5 & 10 & 7.4 & -23.6 \\
2004 & 20 & 13.8 & -16.1 & -27.3 \\
2005 & 11.8 & 17.7 & -1.7 & 5.3 \\
2006 & 8.2 & 12.7 & -23 & -12.3 \\
2007 & & & -16.2 & -9.1 \\
2008 & & & -10.1 & 5.1 \\
\hline
\end{tabular}

Source: IMF: World Economic Outlook Database, 2008

http://www.imf.org/external/pubs/ft/weo/2008/01/weodata/index.aspx [27] and ILO: ILO Database, 2008 http://laborsta.ilo.org/cgi-bin/brokerv8.exe [26], own calculations 
unemployment rate, because the extent of their change is overwhelmed by the enormous inflation rates. Thus, the above indices have proved to be inappropriate for the comparison of the two countries.

The social costs in the transitional countries were unexpectedly large in the early 1990s (Ellman, 1994 [8]; Nelson, 1997 [35]). The development of the standard of living is an important terminant of a regime's legitimacy.

Let us review some of the social indicators to see if there are any differences between the countries which might help us understand the significant difference in the protesting activities.

In Ukraine, the average life expectancy at birth was 69.5 years in 2005, which falls short of the 70.1 level of the 1970's. In Belarus, the average life expectancy at birth was 69.9 years in 2002, which is lower than the 71.5 years indicated in the first half of the 1970s. Government spending on health is $4.8 \%$ in Belarus and $2.9 \%$ in Ukraine in relation to the GDP. Healthcare spending (public and private) on purchasing power parity is USD 464 per capita in Belarus while only USD 176 in Ukraine. The percentage of malnourished population is $3 \%$ in Belarus but $4 \%$ in Ukraine, according to UN data. Public spending on education is $6 \%$ of GDP in Belarus, and $4.2 \%$ in Ukraine. The number of landline phones per 1000 inhabitants was 299 in Belarus and 216 in Ukraine; the number of internet users was 81.6 and 18 respectively.

In the early 1990s the Human Development Index (HDI) started to decline in both countries, with Ukrainian figures starting from a higher level, and declining faster than in Belarus. This trend halted in 1995; the HDI index in that year was 0.756 for Ukraine and 0.755 for Belarus. Since then, both countries have shown some improvement, but while the level of Belarussian HDI index in 2005 was above the 0.790 index of 1990 , Ukraine at 0.788 was still below the 0.809 in 1990 (UNDP 2008 [54]).

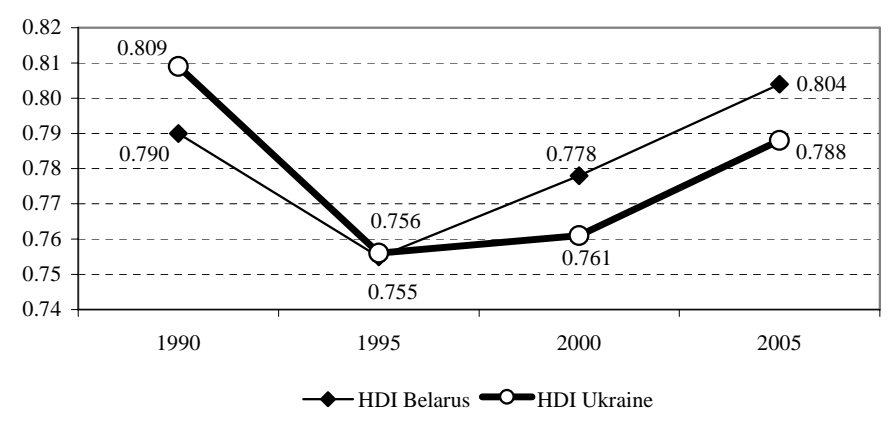

Source: UNDP: Human Development Report, 2007/2008

http://hdrstats.undp.org/countries [55]

Fig. 2. Chart 2: Human Development Index in Ukraine and Belarus (19902005)

These figures, and especially the macroeconomic data, are rather surprising. It is clear that there has been a considerable decline in the standards of living; though social damage was smaller in Belarus. Apart from the oppressing nature of the po- litical system, this economic factor, albeit to a lesser extent, is the cause of the weaker articulation of social discontent in $\mathrm{Be}$ larus.

\section{The possibilities and limits of articulation in Ukraine and Belarus}

Now that we have explored the tensions in society, let us survey the ways society could articulate their dissatisfaction towards the elites in Ukraine and Belarus through the means of elections and civil movements. In our review we will focus on these forums in order to shed light on the democratic/antidemocratic responses of the elites and the affinity of society to use these channels.

The quality of institutions and procedures in connection with political transformations is presented on a numerical scale by the yearly publication of Freedom House. ${ }^{4}$

${ }^{5}$ The figures shed light on the suppressive, antidemocratic character of the Belarussian regime, and on the fact that the possibilities of articulating discontent against the political leadership are far larger in Ukraine.

In our review of Ukraine the emphasis will be on the months of the Orange Revolution. In this country of 50 million inhabitants, the number of anomalies and abuses surrounding elections proceedings had been on a rise since the latter half of the $1990 \mathrm{~s}^{6}$, which meant that the voters had been restricted in expressing their will, but all this changed during the Orange Revolution in 2004. Although a constitutional reform passed in 2003 allowed the then President Leonid Kuchma to run for the Presidency, which is the most influential position in the country, for the third time, he declined this in 2004. Thus, the two contestants for the seat were Viktor Yanukovych (prime minister 2002-2004), and Viktor Yushchenko (prime minister 1999-2001). Nationalism became a significant factor in the political system in Ukraine in the 1990s (Pirie, 1996 [39]). While Yanukovych was supported by the so-called Donetsk-Clan and the Russian-speaking population, and was regarded as the heir of Kuchma; Yushchenko, in the colours of the Our Ukraine bloc and backed mostly by the Ukrainian-speaking population of the west of the country and other western countries, urged a more pro-western approach as well as promised strict anti-corruption measures and market re-

\footnotetext{
${ }^{4}$ The method of choosing and using Freedom House indices could be problematic. However, we do not consider it a relevant or cardinal problem in this study, because we accept Havrylyshyn's and van Rooden's results who showed that there is strong correlation between the similar insitutional indices of different institutes (EBRD, Heritage Foundation, Freedom House, Euromoney) (see Havrylyshyn - van Rooden, 2001 [21]).

${ }^{5}$ The score of 1 signifies the features which characterize an established democracy the most, and 7 is the value of the least characteristic ones. Each figure refers to the previous year, for example data for 2006 refers to the period between the 1st January 2005 and the 31th December 2005.

6 Leonid Kuchma has gained power through a relatively fair competition against Leonid Kravchuk in 1994, but during the following parliamentary elections and the presidental elections in 1999 he did not recoil from using unfair tools.
} 
Tab. 6. Political indices in Ukraine and Belarus (1997-2007)

\begin{tabular}{|c|c|c|c|c|c|c|c|c|c|c|c|}
\hline & & 1997 & 1998 & $1999-2000$ & 2001 & 2002 & 2003 & 2004 & 2005 & 2006 & 2007 \\
\hline \multirow{2}{*}{ Election process } & BEL & 6.00 & 6.25 & 6.75 & 6.75 & 6.75 & 6.75 & 6.75 & 7.00 & 7.00 & 7.00 \\
\hline & UKR & 3.25 & 3.50 & 3.50 & 4.00 & 4.50 & 4.00 & 4.25 & 3.50 & 3.25 & 3.00 \\
\hline \multirow{2}{*}{ Civil society } & BEL & 5.25 & 5.75 & 6.00 & 6.50 & 6.25 & 6.50 & 6.75 & 6.75 & 6.75 & 6.50 \\
\hline & UKR & 4.00 & 4.25 & 4.00 & 3.75 & 3.75 & 3.50 & 3.75 & 3.00 & 2.75 & 2.75 \\
\hline \multirow{2}{*}{ Independent media } & BEL & 6.25 & 6.50 & 6.75 & 6.75 & 6.75 & 6.75 & 6.75 & 6.75 & 6.75 & 6.75 \\
\hline & UKR & 4.50 & 4.75 & 5.00 & 5.25 & 5.50 & 5.50 & 5.50 & 4.75 & 3.75 & 3.75 \\
\hline \multirow{2}{*}{ Governance } & BEL & 6.00 & 6.25 & 6.25 & 6.25 & 6.50 & 6.50 & 6.50 & $\mathrm{n} / \mathrm{a}$ & $\mathrm{n} / \mathrm{a}$ & $\mathrm{n} / \mathrm{a}$ \\
\hline & UKR & 4.50 & 4.75 & 4.75 & 4.75 & 5.00 & 5.00 & 5.25 & $\mathrm{n} / \mathrm{a}$ & $\mathrm{n} / \mathrm{a}$ & $\mathrm{n} / \mathrm{a}$ \\
\hline \multirow{2}{*}{ Administration of justice } & BEL & 6.00 & 6.25 & 6.50 & 6.75 & 6.75 & 6.75 & 6.75 & 6.75 & 6.75 & 6.75 \\
\hline & UKR & 3.75 & 4.00 & 4.50 & 4.50 & 4.75 & 4.50 & 4.75 & 4.25 & 4.25 & 4.25 \\
\hline \multirow{2}{*}{ Corruption } & BEL & $\mathrm{n} / \mathrm{a}$ & $\mathrm{n} / \mathrm{a}$ & 5.25 & 5.25 & 5.25 & 5.50 & 5.75 & 6.00 & 6.25 & 6.25 \\
\hline & UKR & $\mathrm{n} / \mathrm{a}$ & $\mathrm{n} / \mathrm{a}$ & 6.00 & 6.00 & 6.00 & 5.75 & 5.75 & 5.75 & 5.75 & 5.75 \\
\hline \multirow{2}{*}{ Democracy } & BEL & 5.90 & 6.20 & 6.25 & 6.38 & 6.38 & 6.46 & 6.54 & 6.64 & 6.71 & 6.68 \\
\hline & UKR & 4.00 & 4.25 & 4.63 & 4.71 & 4.92 & 4.71 & 4.88 & 4.50 & 4.21 & 4.25 \\
\hline
\end{tabular}

Source: Freedom House: Nations in Transit: Belarus, 2006, p. 1.

http://www.freedomhouse.hu/nitransit/2006/belarus2006.pdf [14]

Freedom House: Nations in Transit: Ukraine, 2006, p. 1.

http://www.freedomhouse.hu/nitransit/2006/ukraine2006.pdf [15]

Freedom House: Nations in Transit: Belarus, 2007, p. 1.

http://www.freedomhouse.hu//images/fdh_galleries/NIT2007final/nit-ukraine-web.pdf [16]

and Freedom House: Nations in Transit: Ukraine, 2007, p. 1.

http://www.freedomhouse.hu//images/fdh_galleries/NIT2007final/nit-ukraine-web.pdf[17]

forms if elected.

The first round of Ukraine's presidential election was held on $31^{\text {st }}$ October 2004 with a record-breaking $75.5 \%$ turnout, the highest in the history of independent Ukraine. Yushchenko gained $39.87 \%$ of the votes, while Yanukovych got $39.32 \%$ (Beichelt - Pavlenko, 2005 [4]). Despite the presidential election reform bill of 18 March 2004, which, for example, allowed each of the parties to delegate 2 representatives to each of the local polling-station committees where they had candidates; there were a great number of concerns about the electoral process and the fairness of the elections. Through channels of the public administration, pressure was put on both private and public sector employees, students and teachers alike to vote for, and even to campaign for, the candidates supported by the outgoing president Kuchma. The media was also heavily biased towards Yanukovych; he featured more prominently than the other 22(!) candidates and the arch-rival Yushchenko almost exclusively appeared in a negative light. In addition to this, the Russian-speaking TV channels, available in most parts of the country, lobbied intensively for Yanukovych. On top of it all, President Putin visited Ukraine a couple of days before both rounds of the election in order to be seen with Yanukovych and gain more votes for him. At least 15 of the 23 candidates were only "technical" aspirants for the presidential seat with links to Yanukovych. With no independent programme or campaign, they agitated for the person and programme of Yanukovych, thereby decreasing the time Yushchenko could appear in the media. These candidates further infringed the independency of the polling station committees, through their representatives (Freedom House, 2005 [13]). Finally, under mysterious circum- stances, Yushchenko suffered dioxin-poisoning in September. It is little short of a miracle that he survived, with dioxin-levels 2200-6600 times the normal concentration in his body, but the scars are visible on his face to this day.

The run-off was held on 21 November, with an $80.4 \%$ turnout and after counting the ballots Viktor Yanukovich seemed to have won, gaining $49.46 \%$ of the votes against the "mere" $46.61 \%$ of votes gained by Yushchenko. Foreign observers complained of serious frauds, especially in the Donetsk region ${ }^{7}$, the hinterland of Yanukovych. Meanwhile, supporters of Yushchenko organised mass demonstrations in Kiev and demanded new elections because of vote-rigging. Donning the orange colour of the Our Ukraine bloc, the protesters had also found the symbol of solidarity. Due to the internal and external pressure, the Ukrainian Supreme Court annulled the results of the run-off on 3 December and the re-run of the second round was held on 26 December. International observers praised the conduct of the vote, which was won by Viktor Yushchenko with $51.99 \%$ to $44.2 \%$ of the votes. With this, the presidential system had also ended, as a constitutional reform in 2004 extended the jurisdiction of the parliament. Starting from the elections in March 2006, the president does not have the right to appoint the prime minister, and the once formal general elections have suddenly had high-stakes, so much so, that Ukrainian politics spent most of 2005 preparing for the elections.

Since 2006 two parliamentary elections have been held in Ukraine and coalition governments were formed. The elections were fair, according to the reports of major international ob-

\footnotetext{
7 There have been four election districts with $100 \%$ turnout, and Yanukovych has won in all of them, with a result of $97-99 \%$.
} 
servation missions. However, the power of the parties of the Orange Revolution has not been stabilized because of the personal conflicts among the parties. Consequently, it could happen in Ukraine that the Party of Regions won the elections held in March 2006 with 32.14\%, formed a coalition government after the election of 2006 with the backing of his rival's Our Ukraine bloc, and Yanukovich has been appointed Prime Minister in August 2007 by Yushchenko. The winner of the election held in September 2007 was also Yanukovich with $34.37 \%$, but the parties of Tymoshenko and Yushchenko succeeded to form a coalition government and Tymoshenko was elected Prime Minister in December 2007.

Civil movements and organizations played an important role in the Orange Revolution as most of the society could not express their own will until 2004 due to the unfairness of the elections. The popularity of NGOs can be seen from their rising numbers: in 1995 there were only 4,000, in 2000 30,000 and by 2004 there were 37,000 non-governmental organizations in Ukraine. The legal framework for non-profit activities is still undefined; therefore they are not eligible for government funds and cannot delegate representative to polling station committees, nevertheless, after all their activities, except donations and membership fees, they have to pay taxes like profit-orientated companies. Almost $60 \%$ of NGOs support themselves from international and mostly western aids, which is why they are eyed suspiciously by many in the parliament. A parliamentary committee in 2004 examining the operation of NGOs decided that western organizations threaten the security of Ukraine through these NGOs (Freedom House, 2005 [12] [13]).

The authoritarian political system of Belarus can be identified with the name of President Alexander Lukashenko, who has started his third term of office since his election in 1994. His presidential career started when in 1994 the president of the Supreme Council, Stanislav Shushkevich (in power 19911994), was removed from office on corruption charges. Instead of Prime Minister Kebich, the winner of the first presidential election of the newly independent Belarus was, by a landslide (45.1\% in the first and $80.1 \%$ in the second round), Lukashenko with a leftist, anti-corruption programme. He owed much of his success to the price liberalization of 1992 and the commencement of privatization in 1993. These, together with high inflation and unemployment rates made his programme, promising the security and comfort of the past, appealing in the eyes of many. His presidency - which was called "sultanism" by Eke and Kuzio (2000) [9] - brought forth the destruction of the already weak democratic establishment, and resulted in the international press dubbing the political system of Belarus as "the last post-Soviet stronghold of Stalinism". During the first years of his presidency he called of privatization, gradually established a centralized governance of the economy, and did not let disparity in society grow. Thus, he had strengthened his basis by introducing measures in the perceivable economy.

Lukashenko also tried to ward off any possible protests. A milestone in achieving total presidential power was the 1996 referendum, which amended the constitution so that the government became totally dependent on the president. His power was further enhanced by the general election in 2000 (boycotted by the opposition), the 2001 presidential election, and the 2003 local election. At these latest local elections the candidates of the opposition gained a mere $1 \%$ of the votes (Freedom House, 2006 [14]). Elections are only formal ceremonies now, marred by the harassment of the opposition-leaders, arrests and the bias of the state-owned media (Amnesty International, 2004 [1]).

At the 2004 referendum to lift the constitutional ban on running for the presidency for the third time, more than $77 \%$ of the electorate voted in favour of the constitutional change, although both the opposition and international observes declared the referendum unfair. Lukashenko managed to retain his power in the March 2006 presidential election, gaining 86.2\% of the votes. Today, parliament and local governments are all but weightless, and public administration leans heavily on the old nomenclature.

As the presidential power grew stronger, the opposition became increasingly marginalized. The lack of public sphere, retaliation against the critics of the government, the trials based on fabricated charges, the forceful suppression of protests and demonstrations have practically eliminated the opposition since the mid 1990s. Some of the leaders and activists of the opposition, among them Yuri Zakharenko, former Interior Minister, have disappeared (Amnesty International, 2004 [1]). Zianon Pazniak, leader of the Belarussian People's Front chose to leave the country and was granted political asylum in the United States (Belarus Miscellany, 2006 [2]).

The government has waged war on independent or proopposition NGOs and the media. There are no independent unions anymore: the arrests of their leaders and the monopoly of the state-controlled "unions" have made the democratic enforcement of workers' interests practically impossible. The Federation of Trade Unions of Belarus, led by Leonid Kozik, has become a puppet of the government. The Federation was the official "initiator" of the 2004 referendum. The unions of independent industries (the automotive and agricultural machine manufacturers) refused the new leadership of the Federation, and tried to retain their independence. The government, in response to this, formed new trade unions in these sectors by legislation integrated the "renitent" sectors into the Federation (ILO, 2004 [26]). Those leaders of the Unions who dared protest or speak out against the measures of the government were arrested for a while (Freedom House, 2005 [12]).

A similar tendency can be seen among NGOs: the loyal organizations are supported both financially and by the media, while independent NGOs have been marginalized and put in an impossible situation, usually by some fabricated reason (Freedom House, 2005 [12]).

Independent media has also been in an increasingly difficult situation. The only independent radio station was banned in 1996 and the bank accounts of about half a dozen independent 
papers were frozen. In 2003, the major independent daily, Belorusskaya Delovaya Gazeta, was banned for three months and the broadcast of the most popular Belarussian-speaking television channel was suspended. The new law on mass communication permits the censorship of the internet, too. Apart from the above-mentioned, the ways of oppressing the independent media and rewarding the loyal media are extensive: ranging from the far-reaching licences of the Ministry of Information to the different cost of publishing and the government funds. As a result of all these, circulation of Narodnaya Volya, an independent daily newspaper has diminished from 80,000 in the mid-90s to 30,000 in the first years of the new century, although the circulation of the major pro-government daily also decreased from 430,000 to 270,000 between 2001 and 2003 (Freedom House, 2005 [12]) which shows the passive alienation from politics and the official propaganda.

The problems of transition have often led to nationalism in the post-communist countries. But in Belarus, where the national identity has been historically quite weak (Burant, 1995 [7]), the official ideology (a peculiar populist-pragmatist mixture of Soviet nostalgia, conservatism, nationalism and anti-westernism) has questioned the independence of the educational and scientific spheres. In education, emphasis is put on teaching ideology and as for scientific works; they must always express the official standpoint. In some educational institutions the leaders supporting the opposition have been removed. As a result of an increasingly open Russification, only $8 \%$ of secondary school children attend Belarussian-speaking schools (Freedom House, 2005 [12]), while only $3 \%$ of broadcast by the Belarussian state television is in Belarussian.

The repressive political system does not allow much room for the articulation of discontent, and inhibits the demand for political and economic changes. Therefore this can be regarded as one of the most important obstacles of transition.

\section{Conclusions}

Following the transformational shock, there is some convergence traceable between the macroeconomic figures (growth rate, inflation rate and unemployment rate) of Ukraine and Belarus. The political systems of the two countries, however, are more divergent than convergent nowadays. Ukraine has embarked on a rapid democratization process, while in Belarus, in an increasing number of areas, the democratic efforts are being cracked down upon.

The convergence of these macroeconomic data must be put into perspective from the three points. Firstly, most of the postsocialist countries are over the transformational recession already, therefore the improvement and convergence of the economic indicators is almost a necessity, though there are a lot of different tendencies in the political systems (parliamentary, semi-presidential, presidential or authoritarian) in the EasternEuropean region at the moment. In other words, the similarity in the political systems, like Minsk and Kiev, is not necessary.
Secondly, Belarus got over the transformational shock sooner than other countries; due largely to administrative interference and external (mainly Russian - see Kuzio, 2001 [28]) economic aid, which also meant that the rapid swing over the recession and the improvements in the perceivable economy helped the Belarussian political elite retain and strengthen its positions (voting system, media, civil society).

This leads us to the third point: the experiments with market economy reforms in Ukraine resulted in recent years in an economic performance slightly worse than that of Belarus, but in the medium and on the long run they might lead to a relatively more sustainable and healthier economic growth path, which could in turn strengthen the positions of the Ukrainian political elite.

To regard the social and economic transformation as an eliteled process, it does not offer endless possibilities to the elite, rather it offers alternatives. The recent collapses of the postSoviet, Eastern-European political systems have had a number of reasons. In the case of Belarus, the reasons helping Lukashenko stay in power are the complete lack of democracy, the brutal oppressive nature of the political system, the support of Russia, and the (relative) alleviation of social damages. The authoritarian power of Lukashenko is based on two pillars: the administrative (but not at all market-friendly) economic policy, prioritizing on the indicators of the perceived economy, and the actions aiming to reduce the channels of the articulation people can use to express social discontent. The power of Europe's last dictator depends on these two pillars, but Lukashenko and those around him will have a major role in shaping these pillars.

\section{References}

1 AMNESTY INTERNATIONAL: Public Appeal - Belarus, 2004, available at http://web.amnesty.org/library/pdf/EUR490112004ENGLISH/ $\{\backslash$ protect $\backslash$ T1 $\backslash$ textdollar\}File/EUR4901104.pdf. downloaded: 02. 08. 2006.

2 BELARUS MISCELLANY: Political Parties of Belarus, 2006, available at http://www. belarus-misc.org/bel-pol.htm. downloaded: 02.08. 2006.

3 BELARUSIAN POPULAR FRONT: Belarusian Popular Front Homepage, available at http://pages.prodigy.net/dr\{_\}fission/bpf/,http: //pbnf.org/. downloaded: 11. 08. 2006.

4 Beichelt T, Pavlenko R, The Presidential Election and Constitutional Reform, Presidential Election and Orange Revolution Implications for Ukraine's Transition (Kurth H, Kempe I, eds.), Zapovit, Kijev, 2005, pp. 5085.

5 Bence Gy, A polgári engedetlenség jogfilozófiai alapjai, A polgári engedetlenség helye az alkotmányos demokráciákban (Lenkei J, ed.) Twins Konferencia-Füzetek, 991.

6 Bunce V, Wolchik S, International Diffusion and Postcommunist Electoral Revolutions, Communist and Postcommunist Studies 39 (2006), no. 3, 283304. (Special Issue on Democratic Revolutions in Postcommunist States),

7 Burant SR, Foreign Policy and National Identity: A Comparison of Ukraine and Belarus, Europe-Asia Studies 47 (1995), no. 7, 1125-1144.

8 Ellman M, Transformation, Depression and Economics: Some Lessons, Journal of Comparative Economics 19 (1994), no. 8, 1-21.

9 Eke S, Kuzio T, Sultanism in Eastern Europe: The Socio-Political Roots of Authoritarian Populism in Belarus, Europe-Asia Studies 52 (2000), no. 3, 523-547. 
10 Etzioni-Halevy E, The Elite Connection: Problems and Potential of Western Democracy, MA, Blackwell, Cambridge, 1993.

11 Fischer F, Sahay R, Végh CA, From Transition to Market: Evidence and Growth Prospects, Lessons from the Economic Transition, Central and Eastern Europe in the 1990s (Zecchini S, ed.), Kluwer Academic Publishers, Dordrecht, 1997.

12 FREEDOM HOUSE: Nations in Transit Belarus, 2005, available at http: //www. freedomhouse.hu/nitransit/2005/belarus2005.pdf. downloaded: 11. 05. 2006.

13 FREEDOM HOUSE: Nations in Transit Ukraine, 2005, available at http: //www. freedomhouse.hu/nitransit/2005/ukraine2005.pdf. downloaded: 11. 10. 2006.

14 FREEDOM HOUSE: Nations in Transit: Belarus, 2006, available at http: //www. freedomhouse.hu/nitransit/2006/belarus2006.pdf. downloaded: 11. 10. 2006.

15 FREEDOM HOUSE: Nations in Transit: Ukraine, available at http: //www. freedomhouse.hu/nitransit/2006/ukraine2006.pdf. downloaded: 11. 10. 2006.

16 FREEDOM HOUSE: Nations in Transit: Ukraine, 2007, available at http://www. freedomhouse.hu//images/fdh\{_\}galleries/ NIT2007final/nit-ukraine-web.pdf. downloaded: 06. 06. 2008.

17 FREEDOM HOUSE: Nations in Transit: Belarus, 2007, available at http://www.freedomhouse.hu//images/fdh\{_\}galleries/ NIT2007final/nit-belarus-web.pdf. downloaded: 06. 06. 2008.

18 Gantner P, Gazdasági és pénzügyi integrációs kísérletek a FÁK térségében, Ministry of Finance, Budapest, available at http://www.pm.hu/web/ home.nsf/O/D491A0D5C82149DDC1256E53004F4AAD?OpenDocument. downloaded: 10. 05. 2006.

19 Greskovits B, Latin-Amerika sorsára jut-e Kelet-Közép-Európa?: Gazdasági reform és politikai stabilitás az új demokráciákban, Politikatudományi Szemle 4 (1995), no. 1, 63-94.

20 Greven MTH, Demokratizáció és intézményépítés, Politikatudományi Szemle 4 (1995), no. 1, 9-20.

21 Havrylyshyn O., Van Rooden R, Institution Matter in Transition, but so do Policies, 2001. IMF Working Paper, WP/00/70.

22 Higley J, Burton MG, The Elite Variable in Democratic Transitions and Breakdowns, American Sociological Review 54 (February 1989), 17-32.

23 _ The Elite Settlements, American Sociological Review 52 (1987), no. 3, 295-307.

24 Higley J, Lengyel Gy (eds.), Elites after State Socialism: Theories and Analysis, Lanham, 2000.

25 International Labour Organization: International Labour Organization Laborsta database, 2008., available at http://laborsta.ilo.org/ cgi-bin/brokerv8 . exe. downloaded: 06. 06. 2008.

26 International Labour Organization: Trade Union Rights in Belarus, International Labour Office, Geneva, 2004, available at http://www.ilo.org/public/english/standards/relm/gb/docs/ gb291/pdf/ci-belarus.pdf. downloaded: 10. 05. 2006.

27 International Monetary Fund: World Economic Outlook Database, April 2008, available at http://www.imf.org/external/pubs/ft/weo/ 2008/01/weodata/index. aspx. downloaded: 05. 05. 2008.

28 Kuzio T, Transition in Post-Communist States: Triple or Quadruple?, Politics 21 (2001), no. 3, 169-178.

29 _ Virtual Foreign Policy in Belarus and Russia, Jamestown Foundation Prism 7 (2001), no. 11, available at http://www.jamestown.org/

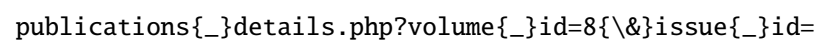
451\{\\&\}article\{_\}id=3855. downloaded: 10. 05. 2006.

30 Lipset SM, Some Social Requisites of Democracy: Economic Development and Political Legitimacy, American Political Science Review 53 (1959), 69105 .
31 Mcfaul M, Transitions from Postcommunism, Journal of Democracy 16 (2005), no. 3, 5-19.

32 Merkel W, Systemwechsel 1. Theorien Konzepzionen. Opladen, 1994.

33 Ministry of Foreign Affairs of the Republic of Belarus: Economic Policy, available at http://www.mfa.gov.by/eng/index.php?id=1\{\\&\}d= economic/policy. downloaded: 10. 06. 2006.

34 Mosca G, The Ruling Class, McGraw-Hill, New-York, 1939.

35 Nelson JM, Social Costs, Social Sector Reforms, and Politics in Post-Communist Transformations, Transforming Post-Communist Political Economies (Nelson JM, ed.), National Academy Press, Washington, 1997.

36 Niemi RG, Bremer J, Heel M, Determinants of State Economic Perceptions, Political Behavior 21 (1999), no. 2, 175-193.

37 O'Donnell G, Schmitter PC, Whitehead L (eds.), Transitions From Authoritarian Rule, Vol. 1-3, Johns Hopkins University Press, Baltimore, 1986.

38 Pigenko V, Wise ChR, Brown TL, Elite Attitudes and Democratic Stability: Analysing Legislators' Attitudes towards the Separation of Powers in Ukraine Europe-Asia Studies 54 (2002), no. 1, 87-107.

39 Pirie PS, National Identity and Politics in Southern and Eastern Ukraine, Europe-Asia Studies 48 (1996), no. 7, 1079-1104.

40 Polanyi K, The Great Transformation. The Political and Economic Origins of Our Time, Beacon Press, Boston, 1944.

41 Plasser F, Ulram PA, Demokratikus konszolidáció Kelet-KözépEurópában, Politikatudományi Szemle 4 (1995), no. 1, 21-42.

42 Portes R, Transformation traps., The Economic Journal 104 (1994), no. 426, 1178-1189.

43 Roland G., The Role of Political Constraints in Transition Strategies, Economics of Transition 11 (1994), no. 4, 27-41.

44 Roland G, Political Constraints and the Transition Experience, Lessons from the Economic Transition. Central and Eastern Europe in the 1990s. (Zecchini S, ed.), Kluwer Academic Publishers, Dordrecht, 1997.

45 Sanders D, The Real Economy and the Perceived Economy in Popularity Functions: How Much Do Voters Need to Know?: A Study of British Data, 1974-1997', Institut de Ciéncies Polítiques i Socials, Barcelona, Catalunya, 1997, available at http://www.recercat.net/bitstream/2072/1294/ 1/ICPS170.pdf. downloaded: 10. 06. 2006.

46 Stark D, Path Dependence and Privatization Strategies in East Central Europe, East European Politics and Societies 6 (1992), no. 1, 17-53.

47 _ Not by Design: Property Transformation in East European Capitalism, Strategic Choice and Path-Dependency in Post-Socialism: Institutional Dynamics in the Transformation Process (Hausner J, Jessop B, Nielsen K, eds.), Edward Elgar Publishers, London, 1995, pp. 67-83.

48 Starr H, Democratic Dominoes. Diffusion Approaches to the Spread of Democracy in the International System, Journal of Conflict Resolution 35 (1991), no. 2, 356-381.

49 Starr H, Lindborg C, Democratic Dominoes Revisited. The Hazards of Governmental Transitions, 1974-1996', Journal of Conflict Resolution 47 (2003), no. $4,450-519$.

50 Szabó K, Az elsóbbségadástól a számítógép-billentyúzetig: Intézmények, konvenciók, közgazdaságtan, Közgazdasági Szemle 41 (1994), no. 4, 298312.

51 Szalai E, Az elitek átváltozása, Cserépfalvi Kiadó, Budapest, 1997.

$52 \ldots$, Gazdasági elit és társadalom a magyarországi újkapitalizmusban, Aula Kiadó, Budapest, 2001.

53 Szelényi I, Szelényi Sz, Circulation or Reproduction of Elites During the Postcommunist Transformation of Eastern Europe, Theory and Society $\mathbf{2 4}$ (1995), no. 5, 615-638.

54 UNITED NATIONS DEVELOPMENT PROGRAMME: Human Development Report, 200762008, available at http://hdrstats.undp.org/ countries/. downloaded: 06. 06. 2008.

55 Vachudova MA, Democratization in Postcommunist Europe: Illiberal Regimes and the Leverage of International Actors, Center for European 
Studies Working Paper Series 139 (2006), available at http://iis-db. stanford.edu/pubs/21255/No\{_\}69\{_\}Vachudova.pdf. downloaded: 10. 06. 2006.

56 Veress J, Gazdaságpolitika, Aula Kiadó, Budapest, 1999.

57 Way LA, Authoritarian State Building and the Sources of Regime Competitiveness in the Fourth Wave: The Cases of Belarus, Moldova, Russia, and Ukraine, World Politics 57 (2005), no. 2, 231-261.

58 _ Pigs, Wolves and the Evolution of Post-Soviet Competitive Authoritarianism, 1992-2005' CDDRL, Center on Democracy, Development, and The Rule of Law, Freeman Spogli Institute for International Studies, Stanford, 2006, available at http://iis-db.stanford.edu/pubs/21148/ Way $\left\{_{-}\right\}$No \{_\}62.pdf. downloaded: 10.06. 2006.

59 Whitehead L, Demokratizálódás: Elmélet és tapasztalat, XXI. Századi Intézet, Budapest, 2001.

60 Williamson J, Economic Consequences of Soviet Disintegration, Institute for International Economics, Washington, 1993. 